REV 2012 is the ninth in a series of annual events concerning the area of remote engineering and virtual instrumentation. The REV conferences are the annual conferences of the International Association of Online Engineering (IAOE) (http://www.online-engineering.org). REV2012 will be organised in Bilbao by the University of Deusto. The general objective of this conference is to demonstrate and discuss fundamentals, applications and experiences in the field of remote engineering and virtual instrumentation. With the globalization of education the interest in and need of teleworking, remote services and collaborative working environments now increases rapidly. Another objective of the symposium is to discuss guidelines for education in university level courses for these topics. REV 2012 offers an exciting technical program as well as academic networking opportunities during the social events.

\section{Topics of Interest}

Topics of the conference include (but are not limited to): Virtual and remote laboratories Remote process visualization and virtual instrumentation - Remote control and measurement technologies - Online engineering - Networking and grid technologies - Mixed-reality environments for education and training - Education and operation interfaces - usability, reusability, accessibility - Demands in education and training, e-learning, blended learning, $\mathrm{m}$ learning, and ODL - Open educational resources (OER) - Teleservice and telediagnosis Telerobotics and teleprescence - Support of collaborative work in virtual engineering environments - Teleworking environments - Telecommunities and their social impacts - Present and future trends, including social and educational aspects - Human computer interfaces, usability, reusability, accessibility - Innovative organizational and educational concepts for remote engineering - Standards and standardization proposals - Products - Military wireless applications - Information security - Telemedicine - Renewable energy - Applications and experiences.

Proceedings

Interesting papers may be published in the International Journal of Online Engineering (iJOE), www.online-journals.org/i-joe/. Indexed by IEEEXplore

\section{PRELIMINARY PROGRAM}

Wednesday $4^{\text {th }}$ :

Morning: GOLC Meeting

Afternoon: Open ceremony, Keynote, Technical sessions. City Hall Tour.

Thursday $5^{\text {th }}$ :

Industry Day: seminars, courses and presentations. National Instruments, Agilent, FESTO, Digilent, EMONA, Certificates of attendance will be given.

Poster and Technical Sessions.

Exhibition Session. Best project/product running.

Boat Tour by the River. Gala Dinner in the Yatch Club. Fiesta.

\section{Friday $6^{\text {th }}$ :}

Keynote and Technical sessions.

Closing ceremony. Best paper award.

Saturday $7^{\text {th }}$ :

Tour Visit to the wine cellars in La Rioja.

Guggenheim Museum Visit.

Presentation of two books:

"Internet accessible remote laboratories" by IGI press and "Using remote labs in education" by U.Deusto.

\section{Invited Speakers:}

Carissa Bohus (1995 Pioneer Remote Lab), David Boehringer, Teresa Restivo\&Gustavo Alves, Manuel Castro.

\section{Important Dates}

- March 16, 2012 - Submission deadline

- April 20, 2012 - Notification of acceptance

- May 18, 2012 - Author registration deadline

- June 15, 2012 - Camera-ready due

Travel Information

Information in www.turismoa.euskadi.net/, www.bilbao.net/bilbaoturismo. Have look to http://www.youtube.com/watch?v=kU3REcHUI64\&feature=player embedded

\section{REV Steering Committee}

Auer M. E., CEO of IAOE, Carinthia Tech Institute Villach, Austria

Ursutiu D., President of IAOE, University Transilvania Brasov, Romania

Al-Zoubi A.Y., Princess Sumaya University of Technology Amman, Jordan

Edwards A., University of Colima, Mexico

Gravier C., TELECOM Saint-Étienne, France

Harward J., Massachusetts Institute of Technology, USA

Henke K.,TU Ilmenau, Germany

Lowe D., University of Sydney, Australia

Orishaba D., Makerere University, Uganda

Honorary Chair REV2012

Oraá J., Rector of University of Deusto, Spain

General Chair REV2012

García-Zubía J., University of Deusto, Spain

Program Chair

Dziabenko O., University of Deusto, Spain

Local Arrangements Chair

Jacob I., Dean of the Faculty of Engineering , University of Deusto, Spain

African Liaison

Orishaba D., Makerere University, Uganda

Asian Liaison

Yu W., Tongji University (CDHAW), China

Latin-American Liaison

Edwards A., University of Colimna, Mexico

North-American Liaison

Sobh T. M., University of Bridgeport CT, USA

Oceanian Liaison

Jan Machotka, University of South Australia, Australia.

International Program Committee

Al-Zoubi A., Princess Sumaya University for Technology , Amman, Jordan

Auer M. E., Carinthia Tech Institute, Villach, Austria Bedaux J., University of Amsterdam, The Netherlands Bouras C., University of Patras, Greece

Callaghan M., University of Ulster, Northern Ireland Cooper M., The Open University, UK

Ferreira J.M., University of Porto, Portugal

Gillet D., École Polytech. Fédérale de Lausanne, Switzerland

Gomes L., Ins. for Development of New Technologies, Portugal Graven O., Buskerud University College, Norway

Gravier C., Université Jean Monnet Saint-Etienne, France

Grout I., University of Limerick, Ireland

Hine N., University of Dundee, UK

Pester A., Carinthia Tech Institute, Villach, Austria Schauer F., Tomas Bata University, Czech Republic Safaric R., University of Maribor, Slovenia

Samoila C., University Transilvania Brasov, Romania Ursutiu D., University Transilvania Brasov, Romania Garcia-Zubia J., University of Deusto, Spain

National Organizing Committee

Angulo I., University of Deusto, Spain Dziabenko O., University of Deusto, Spain Eguiluz A, University of Deusto, Spain Garaizar P., University of Deusto, Spain García-Zubía J., University of Deusto, Spain Guenaga M.L., University of Deusto, Spain Hernández U., University of Deusto, Spain Jacob I., University of Deusto, Spain Orduña P., University of Deusto, Spain Moral, A., University of Deusto, Spain Ruiz-Garibay J., University of Deusto, Spain Rodriguez L., University of Deusto, Spain 